\title{
Carcinoma of the Conjunctiva pT4d TNM
} Finding v7

National Cancer Institute

\section{Source}

National Cancer Institute. Carcinoma of the Conjunctiva pT 4d TNM Finding v7. NCI

Thesaurus. Code C88601.

Carcinoma of the conjunctiva with tumor invading the brain. (from AJCC 7th Ed.) 